\title{
RETHINKING PUBLICNESS: THE PRECEDENCE OF THE RIGHT TO COMMUNICATE \\ SLAVKO SPLICHAL
}

\begin{abstract}
The principle of publicity was originally conceived as a critical impulse against injustice based on secrecy of

state actions and as an enlightening momentum

substantiating the "region of human liberty," making private citizens equal in the public use of reason. Early debates on freedom of the press pointed toward the idea of publicity as an extension of individuals' freedom

of thought and expression. With the constitutional guarantee for a free press in parliamentary democracies, discussions of freedom of the press were largely reduced to the pursuit of freedom by the media,

thus neglecting the idea of publicity as the basis of democratic citizenship. The concepts of public service media and, to a lesser extent, the model of social responsibility of the press attempted at recuperating the latter dimension of publicity, but with very limited

success. The discrimination in favour of the power/ control function of the press clearly abstracted freedom of the press from the Kantian quest for the public use of reason. In democratic societies where the people rather then different estates legitimise all the powers,

the control dimension of publicity embodied in the corporate freedom of the press should be effectively supplemented by actions toward equalising private citizens in the public use of reason.
\end{abstract}

Slavko Splichal is Professor of Communication at the Faculty of Social Sciences, University of Ljubljana, email: slavko.splichal@uni-lj.si. 


\section{Introduction}

Publicness (Ger. Öffentlichkeit) has an important, though always limited influence on all politically relevant actions, and the same is true for the absence of publicness. ${ }^{1}$ The principle of publicity became a "universal good" of the Western hemisphere with the Enlightenment idea of the people as the ultimate source of sovereignty, and of publicity serving the people's needs - an idea that was also in the germ of any conception of press freedom. The universality of the principle of publicity was most clearly stated in Immanuel Kant's and Jeremy Bentham's theories. They both attempted at a universal definition of the principle of publicity, although on substantially different grounds - Bentham on the basis of its utility for the maximisation of the people's happiness, Kant on the principle of right and the need of using one's reason in public. Publicity in Bentham's ethics is derived from the general principle of $u$ tility; as Bentham argued, whatever principle would differ from the principle of utility, it would necessarily be a wrong one. Bentham's principle of utility was aimed at the maximisation of the people's happiness, and only because publicity is instrumental to utility, it could be used as a "standard of right and wrong." In contrast to Bentham, the standard of right and wrong is for Kant publicity in their own right: all actions are wrong if their maxim is not conformable to the principle of publicity. The two great architects of the publicity principle also differed in terms of practical solutions to implement the principle; only Bentham grappled with a detailed plan to make the principle of publicity efficient in practice. The development of modern mass media immensely widened the implied practical consequences of the principle, both for the media and society at large. Yet besides new opportunities, changes in the political, economic and social environments also create new problems in terms of consequences of the practical application of the principle, the most important concerning the relation between the right to private property and the personal right to communicate.

It would be mistaken to promulgate any specific historical form of publicity as a universal functional requirement for the maintenance of publicness in general. The notion of the universality of the principle does not imply uniformity of its empirical appearances. On the other hand, it would be also a failure to renounce all pretensions to the universal normative concepts of "publicness" and "publicity" altogether due to historical variations. In his defence of the concept of the constitution, Kant concluded that "although a perfect state may never exist, the idea is not on that account the less just, which holds up this maximum as the archetype or standard of a constitution, in order to bring legislative government always nearer and nearer to the greatest possible perfection" $(1881 / 1952,114)$. It does not mean that we should look for such an archetype of publicity as a ready-made ideal model constructed in the past that could be applied as a universal solution to the present problems. In the end, what social theorists and philosophers thought and said in the past is perhaps not important per se. Rather, it is the future we have to face. But we would be barking up the same wrong tree, if we conceived of the future independently from the past, since the ideas of freedom of the press that were popular and contested in the eighteenth and nineteenth centuries are reflected and (mis)interpreted by contemporary concerns for human rights and the right to communicate in particular. 
Due to numerous conceptual changes and controversies that arose during the past centuries, a clearly defined concept of publicity would be needed primarily for normative purposes. The modern media definitely lost their "natural freedom" tied to personal liberty of the author: a complex network of relations between the media and political and economic actors transformed the former relatively simple process of mediation between authors and small circles of readers, and between politics and morals, into complex, widespread processes of (public) mediation between economy and politics, which utterly enervated the idea of immediate and universal citizens' participation. All democratic societies are facing the problem of how can the media, old and new, be made accessible to citizens and how they can be used for the benefit of citizens and not only as a vehicle to reach and persuade potential consumers and voters, and to generate profit and power.

\section{Freedom of Expression and Publication as a Natural and Civil Right}

The first powerful ideas of intellectual liberty including free speech and publication were created by great philosophers of the seventeenth century. Milton's defence of freedom of publication in the Areopagitica (1644), though it revoked little response at the time of its publication in several dozen copies, became together with the two centuries younger John Stuart Mill's essay On Liberty (1859), probably the most often cited justification for freedom of expression and publication in English literature. Milton argued that the press should be freed from authoritarian constraints such as the licensing of book and newspaper printing, which would help attain the "utmost bound of civil liberty," that is favourable conditions assuring that "complaints are freely heard, deeply considered, and speedily reformed" $(1644 / 1999,4)$. He pleaded for an unlicensed printing because licensing, like the Inquisition of the Roman Catholic Church, "hinders and retards the importation of our richest Marchandize, truth" (1644/1999, 37). Similarly, Spinoza (1670/1883) argued that uniformity of (public) speech and its subjection to the dictates of the supreme power would represent a tyranny against nature and a calamity both for the state and for the individual, which would be perhaps accepted by "the avaricious, the flatterers, and other numskulls, who think supreme salvation consists in filling their stomachs and gloating over their money-bags," but always resisted by those "whom good education, sound morality, and virtue have rendered more free" (Part 4, 20:45). Laws against freedom of opinion expression would affect "the generous minded" but not criminals, and that would represent a great peril to the state.

The idea of the right to speak freely seems to be a simple one - a "natural right" of individual that is beyond and over any positive legal system - ever since the relativity of the truth and potential erroneousness of individuals' opinions have been acknowledged. The gradual social spread of free opinion formation and expression was an unavoidable consequence of the advances in scientific knowledge, which stimulated the "desire to learn." Scientific findings spread faster and deeper across society and stimulated "lay" interest in reading and publishing with the expansion of general education, particularly after the invention of printing. In contrast to science in antiquity practised as a solitary, even secrete, activity, modern science developing in the Enlightenment became a public activity practised in aca- 
demic communities with a growing authoritative power in society. During the early 1600 s, scientific communities acquired a certain degree of autonomy in thought and action, and by the end of the eighteenth century developed into the "Republic(s) of Letters" - imagined or virtual "empires of thought" whose members could even live in different countries but were connected through letters and literary and scientific journals. The quest for rationality, as a universal norm surpassing cultural, political, and religious cleavages, was not always free of dogmatism in scientific practice and did not directly influence the expansion of freedom of expression and publication; it stimulated individual and social (political) consciousness to comprehend publicness as an epistemological condition of truth and moral-political condition of justice.

Yet it was not only a political-philosophical question of the nature of truth, and the quest for a free scientific debate that pervaded the struggle for mental freedom beyond the philosophic principle of freedom of mind. In the progression beyond the sphere of scientific knowledge, the freedom of speech first denoted the privilege of free debate granted to members of political assemblies. Thus Spinoza insisted "not only that the authority of all the patricians in the decision is equal, and that business is quickly despatched, but also, that everyone has absolute liberty (which is of the first necessity in councils) to give his opinion without danger of unpopularity" (1677/1883, chap. 8:27).

In some countries, such as Germany, the notion of freedom of speech as a privilege restricted to the aristocratic elite was still prevalent in the mid-1800s. The progressive spread of freedom to broader and lower social classes resulted from the economic and political emancipation of the bourgeoisie which, at the end of the seventeenth century and during the eighteenth century, brought about the first institutions of the public — " those social places that are exceptionally important in everyday life for the formation of an opinion of the public: 'the salon' and 'the pub;' both of them sites for meetings of a reflecting, discussing, cleverly chatting, and politicising 'world'" (Tönnies 1922, 202). Freedom of thought, speech, and press are liberties that have been enacted by the bourgeois revolutions as expressions of "the fight of the new-bourgeois, the national-bourgeois class that positions itself as a 'public' — and very often as the 'people,' or the 'nation' — for power, i.e., first for participation in the power of old classes and the monarchy which it restrains, and later increasingly for independent power" (p. 128). By strengthening the power of the bourgeois class, civil liberties also strengthened and became a "universal good" with the Enlightenment idea of the people as the ultimate source of sovereignty, in contrast to former conceptualisations of the people as subjects or servants of the government. The ruling class could not deny the subordinate class those political rights it obtained by fighting for itself "without hitting itself into the face," as Tönnies claimed.

Libertarian and rationalist ideas propagated by Milton, Locke, and Spinoza inspired generations of critical philosophical and political thinkers of the Enlightenment. Most of them also followed their view of a necessary borderline between tolerable and intolerable opinions, which actually — though neither intentionally nor directly - also legitimised censorship as an instrument to protect the sovereign power of the state. Locke, Milton, Spinoza, and their followers believed that freedom (of speech) was inseparable from responsibility. If peace and security in society would be challenged, for example, then a person's right to express and 
publish opinions had to be subordinated to "higher values" and restrained accordingly.

Seventeenth-century liberal-rationalist ideas on freedom of expression and publication generated two different intellectual currents in following centuries. On the one hand, the intellectual inheritors fostered the ideas of free press in the framework of protective democracy. With Utilitarianism the idea of freedom of expression and publication has been instrumentalised in publicity as a means to hold governors accountable to the governed. On the other hand, the idea of freedom of expression and publication, which proceeded from the idea of communication as a generic ability and need and thus natural freedom and right of human beings, remained instrumental in the authentic Spinozean sense - as a right of the individual absolutely necessary for human progress. The former stream of thought, which conceived of publicity primarily as a means of surveillance, prevailed in the nineteenth century and has been effectively institutionalised with the press as the "fourth estate" or "watchdog." This conceptualisation of freedom of the press served as a powerful means, though not always in the hands of the public, of limiting governmental abuse of power. The alternative stream, which was invigorated by the Enlightenment, focused on human generic freedom to communicate and included political philosophers as different as Rousseau, Kant, Marx, and J. S. Mill among others, but it still lacks an authentic institutionalisation of its universal principle of publicity mediating between politics and morals, as first defined by Kant. The opposition between these two currents is crucial. The first rests on functions performed by the public and its immediate instrument, the press. The second is derived from the transformation of natural personal right into civil right to communicate, as a realisation of generic human freedom, embedded in the press as the common means of individuals to communicate their spiritual existence and participate in collective (and particularly political) life, which is determinative of everyone's personal and social identity.

\section{From the Fourth Estate to the Right to Communicate}

During the nineteenth century, the notion of the "fourth power," with newspapers as its legitimate corporate agents, gained popularity over Kant's idea of the "public use of reason" emphasising the personal right of publishing opinions, for it corresponded with the then dominant conception of people's governance as representative government, and the idea of the division of powers. With the myth of the fourth estate, the broader and more comprehensive idea of publicness eclipsed even before a practical attempt was made to enact it constitutionally or legally: it was largely reduced to the concept of "freedom of the press" as the fourth power and to "the right to publish the truth about the government." In terms of Jürgen Habermas's differentiation between the three types of actors acting in the public sphere - (1) those who emerge from the public and participate in the reproduction of publicness (essentially, civil society's actors of the late twentieth century); (2) organisations, political parties, interest groups and similar actors who "occupy an already constituted publicness in order to use it" (they only "appear before the public"); and (3) publicists in the media as gatekeepers who set the agenda of public discourse and control the access of contributions and authors to the mass media that control the public discourse $(1992,440,453-4)$ - the enactment of freedom of 
the press marginalised the indigenous group of actors who historically set up the (liberal-bourgeois) public sphere, and whose participation in it is still unavoidably constitutive.

By the end of the twentieth century, the concept of the fourth estate/power that aligns the media with the executive, legislative and judiciary powers of the state, lost its moral vigour. The surveillance objectives of the early 1800s "deteriorated" into the Progressive utopia of egalitarian social control of the early 1900s, and both were challenged by the critique of the tyranny of majority. Trust in the visions of surveillance subsided due to accumulated power in the hands of the State and incorporated economic power of private capital, with the owners of media corporations becoming part of the power elite composed of top political, economic and military people. Inordinate individualism brought about by deregulated capitalism of the late 1900s made no case for personal liberties beyond freedom of enterprise. Freedom of expression and publication as a personal right has been largely neglected on account of freedom of the fourth estate as the real right, but the latter has been rendered increasingly ineffective in its mission of surveillance because of the profit maximising operations of private media capital and consecutive alliances with power élites muted the bark of the "watchdog." As C. Wright Mills suggested, the rise of the power élite led to a complete absence of a civil service that would not be politically biased and to "the increased official secrecy behind which great decisions are made without benefit of public or even Congressional debate" (Mills 1956/ $2000,296)$. In other words, the once dignified great power of the Public Opinion Tribunal and its main vehicle, the press, in securing public confidence vanished.

Similarly, the free marketplace model of the press "remains an essentially idealist transposition of the model of face-to-face communication to that of mediated communication" (Garnham 1992, 361). This practical model failed to conform to radical changes introduced into the public sphere with the development of the mass press and broadcast media, corporate capitalism, and the modern state. Insisting that market competition of the media is the most important precondition of their freedom assumes, without $t$ warrant, that the right to private property - because everyone has this right - guarantees both freedom of the media (their independence from the state) and freedom of citizens (free choice between different media and contents). Apparently this is an "ideal type of free market" of the media, which in practice does not exist due to the processes of capital concentration and centralisation. As a consequence, the "free" media market is largely oligopolised, and the "free" choice is severely limited by constrained supply. Even for producers, the free market does not ensure free access to the "deregulated" marketplace because of the levels of investment required to enter the market, rising program production costs, and already existing oligopolies. Organisational concentration and conglomeration in mass communication tend to limit the opportunities of independent producers to profitably offer something different from main-stream supply, foster standardisation of program supply across the entire media (particularly television) industry, and create a risk that the main channels of access to the public may eventually be controlled by a small number of strategically placed and minimally accountable gatekeepers (Blumler 1991, 9).

In contrast to the rather abstract Kantian ethical principle of publicity - as an "instrument" to achieve individuals' independent reasoning and legal order in the social realm, and to regulate relations between politics and morals through public 
law — the concrete material form of publicity that has been institutionalised with the powerful mass media entirely suppressed its ethical foundation. This new industrial - form of communication, which became a momentous element of the political and economic system, transformed the very nature of the publicity "mechanism" itself: instead of enabling citizens to use their own reason in public, the media represented them in public following the example of boundless political representation; instead of securing for citizens the personal right to publish opinions, they effectively deprived them of that right.

In contrast, Enlightenment conceptualisations of freedom of the press - centred around the concept of "publicity" and derived from personal right of reasoning, writing, and publishing opinions - brought forth by grand social theories of the eighteenth and nineteenth centuries did not pass an empirical test of history. In addition or, better, in contrast to the narrow conceptualisation of the press as only a means of democratic surveillance, freedom of the press may be conceptualised - as derived from these theories - as a specific historical form and an extension of personal freedom of thought and expression - an extension not merely in the quantitative sense of more of the sameness, but in the sense of diversified opportunities for communication. It is not considered the final stage of the development of human positive freedom of expression, and it is only one among different possible — and different historical — operationalisations of the principle of publicity as the supreme normative concept. An operationalisation of the principle of publicity supplementary to freedom of the press is Kant's right to communicate, which later appears in a Deweyan conceptualisation of the public as increasing the level of social knowledge and inclusion of actors and areas of popular participation.

A personal right to communicate is based on Kant's idea of publicness centred on the universal principle of publicity. Publicity is the necessary condition and principle of all actions relating to the right of other men: if the enacted decisions and laws are not made commonly accessible, their rightfulness is at least questionable if not completely lacking. Yet the principle of publicity can only become the supreme principle of right and legal order, if citizens are able to make their own judgements on the validity of publicly presented claims — which can only be based on a reflective, reasoned act.

Communication as the process of construction of shared meanings is constitutive of human reasoning, which is particularly important in the process of examining the subjective sufficiency of judgements and the pursuit of truth or objective sufficiency of judgements. Human reasoning must be communicable to others, who must be able to be attracted to it through communication. Certain subjective (personal) and objective (societal) conditions should be met for such communication to take place. Every person must be able to attain active citizenship, that is, to become a member, in Bentham's words, of the "tribunal of the public ... forming an enlightened judgment" (1791/1994, 590). The necessary (though not yet sufficient) conditions of public deliberation are personal involvement and reflective distance: the two components of the process are mutually conditioned and restrained.

Besides language competence of actors, communicability of human understanding requires "the courage" to use one's own reason in public and accept the attention attracted by such uses. Only if the three conditions are met can publicity serve as the principle of right (in contrast to obedience that is characteristic of the "private use" of reason, in Kant's sense). In addition, those taking part in transactions 
having significant consequences for those not participating have an ethical obligation to make those judgements or actions public.

The public formed of self-dependent citizens who participate in the process of will-formation is the condition for the principle of publicity to become universal; and it is congruent with Kant's categorical imperative - "Act only on that maxim through which you can at the same time will that it should become a universal law" - only if it is universal. In Kant's system of publicness, there are two principal components of the principle of publicity: the systemic principle of justice and the personal right to public use of reason or, in its contemporary version, the right to communicate. I see five clusters of rights and corresponding conditions pertinent to the modern complex world of mass media, which may be listed as constituent elements of the citizen right to communicate:

1. Right to be given information and related rights and duties:

- Accessibility/Surveillance: All actions (in the political assembly or elsewhere) with implications for those not participating must be subject to the surveillance by the public. If the enacted laws and actions are not made commonly accessible, their rightfulness is questionable. Surveillance is an interactive process: all those who are exposed to surveillance may take an active part in publicity, having the right of transmitting information and opinion in public.

- Hospitality: foreigners and non-citizens must have access to national publics.

2. Right of transmitting information and expressing opinion and related rights and duties:

- Tolerance for judgements of approbation and disapprobation.

- Tolerance of non-authentic publications.

- Tolerance and receptiveness for judgements expressing dissenting or minority opinions and different cultural identities.

- Freedom of social inquiry and of dissemination of its findings.

3. Right of free access to the media and related rights and duties:

- Accessibility: if communication means are not made commonly accessible for, communicability of opinions cannot be materialised. Right of access can only be restricted if not violating the principle of equality of citizens.

4. Rights and duties enabling citizens to participate in public communication, decision making, and in the management of the media:

- Regulatory rules: Publicness not only implies the involvement in the regulation of long-term consequences of transactions in which individuals are directly not involved yet seriously affected in a general sense, but particularly participation in systematic regulation of communicative actions. Publicity is a means to regulate human actions that exist independently of publicity, but regulatory rules are also constitutive for the publicity itself, and citizens must have the right to discuss them.

- Regulatory bodies: Censorial or controlling function of public opinion has to be performed not only outwardly (thus legitimising rightfulness of public actions), but also inwardly (protection against abuses of publicness). Citizens must have the right to be informed about, and to participate in, decision making or other actions of press and broadcasting councils, courts of honour, and management organs of public service media. 
5. Corollary related to constitutive conditions of public expression of judgements:

- Rationality/Reflexivity (in the sense of Kant's "method of enlightenment") is not only allowed but requested of all participants in the public discourse. Publicity serves as an asymptotic criterion of rationality because it fosters critical faculty of weighing every judgement with the collective reason - "not so much with actual, as rather with the merely possible, judgements of others, and by putting ourselves in the position of everyone else" (Kant 1790/1952, 519).

- Communicability: Universal communicability is what every one expects and requires from every one else in public discourse, which makes public communication possible. Kant believed that what is rational is always publicly communicable. Dewey would strongly disagree; he realised that "presentation is fundamentally important, and presentation is a question of art" (Dewey 1927/ 1991, 188); a "scientific" presentation could not attract the attention and stimulate (re)actions of members of the public, with the exception of a few intellectuals. Forming opinions on public matters calls for "a subtle, delicate, vivid and responsive art of communication" (p. 184). Otherwise, social sciences would be assimilated to physical sciences, which is but another form of absolutism.

- Educativeness: The involvement in public discussion of social problems at least creates a public "spirit" inclined to rational discussion. Public debates have to be regulated in a way to make the media and the public sphere accessible to the groups remote from parliamentary institutions, and to stimulate an increase in individuals' knowledge. Intelligence and reflexivity are not "personal endowments" that one inherits but are social in their very nature; thus an appropriate system of education is essential for the development of human ability and need to communicate.

The realisation of the civil right to communicate in modern democratic societies requires a level of resources proportional to the increase in its complexity since it had existed as a natural right to communicate. Only as long as the individual's relation to his or her language was determined by his or her membership in community - that is, as a component of the relation of a "natural" member to his or her human community - the right to communicate existed as a natural right of human beings, which they could not alienate (or else they would cease to exist as human beings).

Early critics of restraints on free printing saw the press as one of many equivalent forms of human communication, arguing that no specific regulation was needed for any of them, including the press. Thus Milton claimed in Areopagitica that "If we think to regulate printing, thereby to rectify manners, we must regulate all recreations and pastimes, all that is delightful to man" - including music, dancing, and even day-to-day conversation (Milton 1644/1999, 22). This not only would ask an immense number of "licencers" to examine all the different forms of communication, but would be also meaningless on the ground that "evill manners are as perfectly learnt without books a thousand other ways which cannot be stopt" (p. 20).

Adam Smith and other liberal political economists of the eighteenth century and subsequent generations believe(d) that the market itself offers a powerful system of social co-ordination matching individual wants with available goods. This idea was largely applied also to the "marketplace of ideas" that undervalued the 
significance of normative issues for democracy in general and specifically for the materialisation of freedoms of expression and publication, with no distinction between different kinds of human communication. The idea of a "free marketplace of ideas" effectively vindicated the processes of commercialisation and commodificiation of the communication sphere, based on the liberal conception of negative freedom (freedom from political authorities). As a consequence, press freedom increasingly became freedom of the press - a freedom of those who owned communication means rather than (all) citizens.

In the second half of the nineteenth century, the critique of press censorship went beyond economic liberalism and utilitarianism. It took up the critique of market economics criticising the normative blindness of the market and focused on the role of restitutive rather than repressive law - on organic rather than mechanical solidarity in Durkheim's terms - to emphasise the right of equity for diverse individuals. Within this context, the legal framework of press freedom, or the notion of its regulation, lost its repressive character and became clearly seen as a core institution of democracy, which brought into the focus of the critique normative issues and social solidarity as key aspects of democratic society. Early writings of Karl Marx (in contrast to his later work, which laid great stress upon issues of material interest and power) and John Stuart Mill, and even earlier ideas of Jeremy Bentham represent, in different ways, an explicit break with an idealised picture of the free marketplace of ideas that ought to exist almost without any societal, legal or governmental intervention.

Within the philosophical discourse of Immanuel Kant, the contradiction between economic market and communication is reflected in his differentiation between the exchange of things and exchange of thought. Kant made clear in his comparison of money and books that both money and books can only be used in the process of alienation or exchange; yet books represent "the greatest means of carrying on the interchange of thought," in contrast to money as "the greatest and most useable of all the means of human intercommunication through things" (Kant 1790/1952, 423; emphasis added). The essence of the book (or newspaper, we may add) is not in being a thing - another point resumed by Marx in his polemic against the liberal economist understanding of press freedom as freedom of ownership but a discourse of the author with the public. Like books, newspapers and other media that developed in the twentieth century are not natural things one is rightfully allowed to occupy, but a contract is needed to regulate the transactions of thought in society, not merely transactions of things in the way of sale and purchase that the marketplace regulates. Despite the fact that communication technologies are obviously "corporeal things" (material substance) that one can "occupy," such acquisition of things does not entitle us to consider the right to acquire a communication means, a medium such as newspaper for example, a "real right," which Kant defines as "a right as against every possessor of it." Rather, the right to acquire communication means should be considered a contractual right, as in the case of division of labor and transaction between the author and the publisher, where "the author may be said to speak publicly by means of the publisher" (Kant 1797/1952, 425).

While both are forms of human transaction, exchange through books (newspapers) has a different function than exchange through money; it is subjugated to specific principles and thus needs specific regulation. Early institutional regulations of 
mass communication limited the autonomy of individuals in the formation and expression of opinions by a free discussion to issues that were not critical of the power élites. Since the very beginnings, the institutionalisation of communication gave rise to different kinds of distorted communication, which resulted from attempts by private and governmental groups to structure and limit public communication in order to enforce their interests. The intensity of institutional regulation culminated with the rise of print media, first in the form of a strict limitation of freedom of expression and publishing (secrecy and censorship) and later in the form of constitutional and legal enactment of press freedom.

With the development of writing, human generic ability and need to communicate ceased to exist as a natural right, which is why Marx and Engels considered the development of writing the birthmark of both civilisation and class society. The idea of communication as a natural human ability possessed and practised equally by every member of a collectivity merely because of his or her membership of the collectivity became definitely untenable. Writing transformed communication from an entirely natural relationship (as it had been in a primitive collectivity) into a social (or as Kant would argue, "civil") relationship because it moved communication from the sphere of no-property (the mere ability to speak is not possible to alienate, thus it cannot be appropriated externally) to the sphere of property. Writing enabled the separation and thus alienation of the message from the sender, just as any other good can be separated from the producer. This helped create the illusion that the messages in their material form of "things" (e.g. in the form of books or newspapers) could be subject to real right, and consequently that freedom of the press could be a species of freedom of ownership. As a matter of principle, however, "a personal positive right against another can never be derived from the ownership of a thing only" (Kant 1785). The negative ownership of a book or newspaper (a copy of it) justifies the negative right to resist any one who would hinder me from the use of this thing at pleasure, whereas a corresponding positive real right could only proceed from a particular (additional) contract, but not from the mere ownership of the thing. In the case of communication, such an additional contract can only be based on the communication contents thus could not obviate the author.

Since communication belongs to the sphere of inalienable personal rights, all forms of communication, including the press or media generally, should be primarily regulated according to the principles of personal right. On that account, expressing opinions should become a civil right of citizens in the civil state of society, as it had been a natural right in the natural state of society. And that is exactly what Kant proposed in his transcendental formula of public law, which requires that all actions relating to the right of others be congruent with the principle of publicity. Indeed, publicity should be considered the central part of public right, which is aimed at the establishment of the harmony between morality and politics.

With the emergence of new media, lines between different forms of media are blurring, making it increasingly difficult to construe medium-specific definitions of rights. This process actually reveals the unity and totality of different - from interpersonal to mass mediated - forms of communication, which makes highly problematic any preferential treatment of professionalised and institutionalised forms of "the press" or "the media" against citizens' public yet much less formal practices of communication in the Internet. In other words, after two centuries, 
technology is now forcing us to reconsider the division between personal rights of thought and expression, and the real rights of the media, which has been established in consequence of an earlier technological innovation - the development of the mass-produced and profit-oriented newspapers.

\section{The Property Right and the Right to Communicate}

The true sense of freedom of the press is not, according to Kant, surveillance of the sovereign, but the right of citizens to publish their critical opinions. As he wrote in 1793 in his article in Berlinische Monatsschrift, every citizen should have the right to "make his opinion publicly known regarding what appears to him to be a wrong committed against the commonwealth by the enactments and administration of the sovereign. ... Hence the liberty of the press [die Freiheit der Feder ${ }^{2}$ ] is the sole palladium of the rights of the people" (1793/1914, 40; emphasis added).

Freedom of the press, though an extension of freedom of thought and speech, cannot be considered exclusively an innate right (which belongs to every one by nature), but a combination of innate and acquired rights. Adopting, expressing, and publishing opinions represent different kinds of acts and, thus, personal rights despite the fact that they all belong to the category of personal right. It is true that "holding a belief or opinion ... does not itself impinge upon the freedom of anyone else, and the exercise of the right to freedom of thought is therefore simply an exercise of the innate right to freedom" (Guyer 2000, 238). However, expressing a belief or an opinion does not belong exclusively to the "inward domain of consciousness" of individuals, but always also concerns other people, as J. S. Mill indicated. Still more, publishing opinions in the press (or other media) falls in the much more complex domain of the "combination among individuals," because it presupposes - in addition to the innate mental predisposition and ability of the individual - ample productive means, including the resources of others that are necessary for making opinions available to others or to the public (e.g., a printing office).

The right to publish exceeds the innate negative right of the author to prevent others from receiving his opinion. It implies the right of access to the means - not any more merely his innate mental abilities - necessary to make an opinion deliverable to others. Mill noticed that the "liberty of expressing and publishing opinions may seem to fall under a different principle" than the liberty of conscience, "since it belongs to that part of the conduct of an individual which concerns other people" (Mill 1859/2001, 15-16), but then he decided not to separate the former from the latter, because it is no less important than the liberty of thought. One could say he renounced treating the liberty of expressing opinions as a liberty different from the liberty of thought for "strategic reasons" - to provide to the act of publication the same amount of negative freedom as to the act of thought, since it was negative freedom (tolerance, non-interference) which Mill was primarily concerned about, and the analogy with freedom of thought would make freedom of expression less contestable. Similarly, Guyer $(2000,258)$ argues that "one person's adoption or expression of virtually any belief whatever does not give anyone else a right to intervene in the former's exercise of his freedom in this form" (emphasis added).

Notwithstanding, freedom from interference is only a negative definition; positive definition must relate to the categorical imperative. And even more, if we fol- 
low Kant, it is not merely freedom at stake, it is a positive right! Talking positive rights is quite a different matter. The personal right to publish, which implies the real right of access, may conflict with the property right, which is a real right concerning an external thing. The question then arises as to which of the two rights is superior? Or which infringement is less of an evil: the limitation of the personal right of publication by the real right of property, or vice versa? Consequently regulation is needed not only to secure the rule of law in the sense that nobody should constrain, or be constrained by, the opinions of others but also to secure the personal-real right of publication.

Judging by Rousseau's and Kant's words, the right of publication should have a superior status. Both Rousseau and Kant suggest that the (civil) right of property be based on, and (potentially) restricted by, public opinion, which can only exist under the provision of the principle of publicity; without publicity no public opinion can develop. Rousseau denoted public opinion as the most important type of law because the implementation of all other laws, including those regulating the property right, depend on it. Kant essentially followed Rousseau's idea, considering property right (except hereditary right to possession) constitutive of the civil state of society which, however, is created through public opinion. The conviction that the right to publish, which is - together with the duty of publicity to be carried out by the necessity of acting from respect for the law - central to the principle of publicity, is superior to the right of property does not imply that the latter may be abolished; yet it may be limited by public regulation in the ways suggested already by Rousseau, Kant, and Mill. If there is a case against the libertarian conviction that liberty is inconceivable without private property as the absolute right, it is the case of the press. Even Kant conceded that the condition for a citizen to be his own master was not necessarily private property (Kant 1793, 246).

A similar line of thought was taken by the UNESCO International Commission for the Study of Communication Problems chaired by the late Sean MacBride:

The freedom of the citizen to gain access to communication, both as recipient and contributor, cannot be compared to the freedom of an investor to make a profit from the media: the former is a fundamental human right; the latter permits the commercialization of a social need (MacBride 1980/1984, 39).

The belief that the property right ought to be superior to the right to communicate is based on the erroneous consideration of freedom of the press as a real right concerning an external thing (newspaper), rather than a personal right concerning individual reasoning, writing, and publishing opinions, which is not determined by the ownership of things. If this belief lacks objectivity, however, it does not also imply that liberty in general is conceivable without (freedom of) private property, neither does it contradict the well-grounded warnings against the dangers of bureaucratisation and legal over-regulation brought about by socialism and expansion of social-welfare state based on the severe limitation, or even the abolition, of the private property right.

Kant's hesitancy about private property as the condition of being one's own master was reconsidered by Habermas in his "Further Reflections on the Public Sphere." He derives the argument for the depoliticisation of private property from the Enlightenment, specifically, Kant's notion of the sovereign as the body politic consisting of all citizens: 
After the universalization of equal civil rights, the private autonomy of the masses could no longer have its social basis in the control over private property ... Their private autonomy had to be secured through reliance on the status guarantees of a social-welfare state. This derivative private autonomy, however, could function as an equivalent of the original private autonomy based on control over private property only to the degree to which the citizens, as clients of the social-welfare state, came to enjoy status guarantees that they themselves bestowed on themselves in their capacities as citizens of a democratic state (Habermas 1992a, 434).

Similarly, Marx $(1844 / 1974,354)$ argued that it was only the political rescission of private property in suffrage that de facto provided the full recognition of the private character of property.

Although the right of publication is not primarily a real right, it nevertheless implies a characteristic of real rights - a duty or obligation imposed upon all others, the community, in respect to the external thing (i.e., communication means external to communicator). In contrast to real right, which does not necessarily assume physical detention of an external thing by the owner (because real right is a pure juridical connection), the right to publish opinion as essentially a personal right paradoxically implies the actual, physical use — but not necessarily legal possession - of an external thing: the medium of publication (communication). I cannot write without a pen (or computer), I cannot make a phone call without a telephone, I cannot address the public without having an appropriate communication means at disposal - a newspaper, a broadcasting studio publicly transmitting the program, or at least access to the Internet. Using some of these media may impinge upon the same rights of others at least because the available real public space and time are limited (as in contrast to the imagined "public sphere").

This rough natural restriction of communication is further complicated by the normative restriction, since "democratic talk is not essentially spontaneous but essentially rule-governed, essentially civil ... not necessarily egalitarian but it is essentially public" (Schudson 1997, 298-9, 301). Communication can only take a democratic shape if it conforms to specific norms that differentiate democratic (civil) communication from communication in its natural state. Norms of democratic communication refer to both the form and the contents of communication. For example, democratic norms may define specific procedures of opinion expression; they may even require the withdrawal of some issues from conversation, such as religion or minority rights. Not the fact of communication itself, but ethical and legal norms that govern it determine its specific democratic nature and functions.

Dewey pointed to the absurdity and infantilism of the belief that a perfect freedom of thought and communication has been achieved because all legal restrictions on freedom have been removed. The mere removal of "negative conditions" does not suffice; what is rather needed is "positive freedom," which Dewey considered "not a state but an act which involves methods and instrumentalities for control of conditions" (1927/1991, 168). Similarly to Marx and many other social theorists of the late nineteenth and early twentieth centuries, who wrote that the main threat to freedom of the press is its subordination to the entrepreneurial freedom, Dewey thought that the main danger to democracy was represented by the tendency of politics to become just another business (p. 182). He saw the central 
problem concerning the formation of opinions in the public and distribution of knowledge among its members through the press in political domination and subordination to big business, which was reflected in the growth of "extra-legal agencies" competing with the government as the "nominal organ" of the public (p. 119). After all, it was not a privilege of freedom that was granted to the (political) press because of its commercial inducement; it was universal freedom of expression because the press was deemed an irreplaceable means for a full realisation of the personal right to express opinions in public - even if the latter was just a pretence for the former. Wolfgang Hoffmann-Riem $(1986,130)$ similarly argues that "the concept of individual self-fulfilment and of citizens' rights to self-government ... has been a key determining influence on the historical definition of freedom of communication in Western Europe," in contrast to the present time that is characterised by the rise of an "economic interpretation" of press freedom merging "the right to communicate" with "the right to run a commercial business."

\section{Personal Right to Communicate as a "Privilege" of Social Groups}

All social and technological changes we have experienced in the twentieth century do not justify in itself the rejection of the enlightened idea of publicity. As Dewey argued in the controversy with Lippmann, "Until secrecy, prejudice, bias, misrepresentation, and propaganda as well as sheer ignorance are replaced by inquiry and publicity, we have no way of telling how apt for judgment of social policies the existing intelligence of the masses may be" (Dewey 1927/1991, 209). These changes point toward the need for major changes in practical forms of publicity to preserve the democratic virtues embedded in the original idea(s) of publicity as universal norm to regulate public discourse. New forms of publicity surely cannot take rise without a broader process of re-shaping the public sphere and, specifically, media institutions and forms of media representation. Dahlgren (1995, 11-16) rightfully emphasises that an important role in this process play the total social structure, which includes all the institutional arrangements of society from social stratification to the entire educational system and its place in the social order, and different forms of sociocultural interaction - from non-mediated face-to-face communication or "the public sphere beyond the media" to the interface of media and citizens. Although new procedures of mediatization and representation, which dominate in postmodernity, and their social and political consequences may seem to suggest that we should leave off the universal Kantian concept of publicity, this turn would be so radical that the question is in place as to whether all the new diversified opportunities and practices of reception and consumption in (mass) communication still help form and express opinions in public and by the public, which authoritative institutions must take into account. Thus a more "conservative" approach focused on the counter-factual entity of publicity still seems to be more adequate, for without the central concept of publicity, the significance of the media for democratic political process is depleted altogether.

A democratic system should provide informed decisions on public issues, and this can only happen on the basis of an open information and communication system that allows for the personal right of public expression or "public use of reason" in different forms of communication. With no public use of reason in the 
media, which is based on the right of citizens to be heard, there is no democracy. With public use of reason only in the media, there is no democracy either: democracy also rests on the principle of dialogue, not only mass dissemination.

The true sense of a democratic regulation of communications is equal availability of influence on different forms of public communication, particularly mass media, to all citizens, so that no citizen would have more institutionally-guaranteed influence over public (or collective) affairs than any other. Legal regulation should guarantee individuals' distinctiveness and uniqueness as the basis of their equality, for people are not equal in the sense, as Dewey (1927/1991, 150-51) stated, that each individual is actually substitutive for any other, but only as much as any distinctiveness and uniqueness of them is truly respected and valued, irrespective of physical and psychological inequalities.

Like any activity exhibiting influence, communication activity can be controlled either internally or externally. Attempts at democratic regulation are often confronted with external sources of inequality of influence (e.g., inequality of income and wealth). Any universal provision of equal rights ensures equal availability of influence only under the provision that such external sources of inequality of influence do not exist. But this is not a very realistic condition. Clearly, the view on which the number of votes a citizen has should depend on his or her taxable income - an option Mill had in mind - or any other external inequality would be considered anti-democratic today because citizens would be unequal in terms of votes. Yet this is usually not the case with an unequal availability of other forms of influence in a number of activities in the public sphere. Citizens are extremely unequal in terms of their access to the media to publish their opinions, or to participate in public discussion. These are typical examples of external sources of inequality where the abolition of legal restrictions (e.g., censorship) does not yet represent a "positive condition" for intellectual freedom. We can easily agree with James Bohman's estimate of democratic societies: "While greater inclusion in wider rights of citizenship has been achieved, social and economic inequalities seem to have widened, and the scope of political decision making seems to have narrowed as the effectiveness of the available regulatory mechanisms for self-rule now seems less likely to bring the process of globalisation and technoscience under control" (Bohman 1999, 176).

Personal public use of reason cannot be realised and the right to communicate not achieved by a mere extension of the control paradigm established in relation between the media and political authorities as the fourth estate model to the relationship between media audiences and the media - so that audiences would be able to actually watch the media, rather than just receive their messages. The solution is the (re)organisation of the public sphere according to the principle of $c 0$ operation, as "a cooperative product of communication and reciprocal influence" (Cooley 1909/1993, 121). The idea of the division of labour might be more appropriate to assure specialisation and independent actions of different power and public actors, and their mutual interdependence, than the principle of the "separation of powers" that can only ensure an effective mutual control. Whereas the idea of the separation of powers is based on mutual mistrust, the idea of division of labour presumes mutual trust and co-operation. At the same time, any regulation has to stimulate an increase in individuals' knowledge and widen access to the public sphere to groups remote from parliamentary institutions. The empowerment of individu- 
als with "communicative power" would pave the way for an effective social communication and public use of reason. An increase in individual communicative power would stimulate the development of a more democratic institutional framework making the public use of reason central to the possibilities of democratic reforms. From this perspective, the concept of freedom of the press has definitely proved insufficient as an ethical and legal principle. In normative terms, this calls for a "radical democratisation" not only of the media, but also of political and economic systems representing the societal context of the media.

The success of new regulatory ideas does not depend primarily on new technological possibilities, increase in the communicative power, and the feasibility of theoretical assumptions, but rather on the power relations between key actors in society. An illustrative solution to the problem of unequal access might be the institutionalisation of the "fair marketplace of ideas" (Brighouse 1995), which "transforms" the personal right to publish opinion into the right of opinion to be published. In contrast to the naive marketplace of ideas, the regulation should allocate equal time and space to each specific view presented, or to each "public policy option," rather than to each individual or opinion agent. This is an idealisation; in practice, space could normally be allocated only to political actors (e.g., parties) or tendencies (interest groups, movements) that will de facto organise the allocation of space to each issue. In other words, if a number of individuals or parties hold the same opinion, they would receive altogether only "one unit" of time or space in the media.

This is not a new idea. In theoretical terms, it represents an operationalisation of Cooley's idea of public opinion as a process of representation in the sense that "the preponderant feeling of the group seeks definite and effectual expression through individuals specially competent to give it such expression" (1909/1993, 124). Looking in the opposite way, competence of an individual does not imply special personal right - based on external restraints, as it is the case of the media under the fourth estate model — but is a privilege to be "used" by social groups. In practical terms, ideas to encourage heterogeneity of media contents were well known already at the beginning of the twentieth century. Hayes argued in 1926 that the U.S. government should regulate by law the publication of newspapers in order to support the development of an informed public opinion, so that each newspaper would be obliged to give an equal amount of space to each of the four leading political parties in the last elections for the presentation of their ideas (in Wilson 1962, 81). Similar ideas can be found in Tönnies (1922). Many European countries regulate in this way (public) television broadcasting during election campaigns. The ethical principle of "fair and balanced" reporting reflects the same basic idea of the need for content diversity in the media reflecting the diversity of interests, orientations, and needs among citizens. Yet a substantial discrepancy exists between media flattering citizens (or rather consumers) - by corresponding and, however fugitively, representing their interests - and citizens' self-dependent access to the media. A similar level of discordance exists between the comprehensive meaning of the universal ethical principle of publicity and its legal operationalisation(s) that ought to assure its practical enforcement as a citizen right to communicate.

The idea of public service is (still) central to the democratisation of the media, particularly broadcasting media; moreover, it is a "natural" setting for the realisa- 
tion of citizens' right to communicate. The idea of public service appeared even before the emergence of radio, as a consequence of the subordination of newspapers to powerful political and/or commercial interests in the late nineteenth century. Many press reformers pleaded for "security valves in public life" based on charitable funds, which ought to limit the dependence of newspapers on political parties and advertisers, prevent sensationalism, and empower "voices of people [to] find their direct expression in the newspaper" (Tönnies 1922, 575). Although Tönnies believed, following the American sociologist J. W. Jenks, that "we will never have a newspaper which will report completely independently about problems of public life unless we have a newspaper that will be independent of circulation and advertising business" $(1922,184)$, he recognised the need for radical reforms of the press to improve the quality and ethical standards of journalism and to make newspapers a genuine organ of public opinion. ${ }^{3}$

Since its first institutionalisation in Europe, public service broadcasting was attributed democratic functions that the press has been progressively losing due to its increased political and commercial dependence. In addition to the goals justified by "public" interest - such as the promotion of national culture and integration, providing contents for minorities and specific groupings such as children, universality and quality programming in the fields of information, education and entertainment - public service broadcasting was always considered also a forum of public debates on political issues and a mechanism of surveillance of political authorities. It was not considered merely an institution established with the consent of the people through their representatives acting for the permanent good of the people - in analogy with the representative government as defined by Edmund Burke - but also designed to enable and stimulate individuals as citizens to take active part in mediated civic discussions and agenda setting aimed at influencing actions of authoritative institutions, i.e. to participate in the formation and expression of public opinion (Splichal 1999, 34). The latter function of the media has never been fully materialised in practice for both societal and technological reasons. The development of advanced technologies of computer mediated communication and global computer communication networks may shape differently — but not determine - the future of democratic communication, fostering the optimistic conception of cosmopolitan citizenship supplementary to the citizenship framed by nation-states. Optimism is not based on the trust in an unlimited power of new technologies to democratise society but, just the opposite, on the belief that political and economic systems can be changed in the way to make it possible for an individual participatory use and collective citizen (public) control of communication goods.

Internet is particularly appropriate to initiate processes of casting away prejudices preventing relevant problems from appearing in the agenda of public opinion. Indeed, with the new interactive virtual spaces it has created, the Internet substantially increased the feasibility of citizens' public use of reason activating tendencies and capacities of innovation and change. Specifically, the Internet had a constitutive role in the development of an informal global communication network of individuals, organisations and movements, which create a sort of international civil society leading toward a genuinely cosmopolitan public. The Internet brought about a new form of publicness - mediated and dialogical at the same time - supplementary to the mediated publicness constructed by traditional mass 
media. Whereas the mass media primarily extended the possibilities of passive visibility (i.e. of one being made visible by producers of media contents), the Internet is based on wide-spread active participation. In contrast to the Internet, traditional mass media favour and facilitate primarily reception and consumption through imitation owing to the market mechanisms and tendency of profit maximisation that stimulate only publication of ideas and news stories that would not annoy or confuse their consumers. Whereas traditional media often help block innovation, particularly when they are heralds of particularistic interests of powerful interest groups behind them, the Internet is pluralistic in terms of both producers and users, and diversified in terms of contents by its very nature - due to its decentered structure. If the concept of public/ness has been determined by the internally confined model of a community gathering by the end of the twentieth century, as Bohman $(1996,106)$ suggests, the rise of the Internet definitely helped transcend this limitation.

From the late nineteenth century, the industrialised, profit-oriented press progressively "occupied" the pre-modern public spaces and privatised them. Whereas every citizen has had access to the public space of the ancient agora to speak to, and be heard by, his fellow-citizens, privately owned newspapers - while they substantially expanded the "public space" beyond the limits of physically attainable spaces - severely limited the possibility of an active citizens' participation in the newly created (virtual) public space. The right to communicate - if enacted may now legally reopen general access to public spaces formerly restricted to élites in control of the press and other mass media. The Internet already tenders practicable online services such as electronic chat rooms and discussion forums that enhance political deliberation in practice.

Compared with the traditional media, however, the Internet is much less capable of digesting ideas and presenting them in a form that would influence the authorities to heed them. The Internet is not controllable; it proved essentially inaccessible to any (national) regulatory attempts (e.g., if national authorities forced an Internet provider to remove some web pages, their producers could move them to another provider outside of the country). However, it can also hardly perform the role of a watchdog or create moral obligations in a way similar to the traditional media. The Internet is neither a Panopticon controlling its users/producers nor a public opinion tribunal controlling the traditional branches of power. Internet technology enables dialogical communication that can hardly be restrained by external surveillance, but at the same time it can hardly assure any response. While the Internet presents new opportunities for social interaction, it also stimulates "fragmentation" and "reparochialization" (Slevin 2000, 181). Nevertheless, the Internet is a perfect communicative environment that enables reflexive reasoning of participants - to detach themselves from the subjective personal conditions of their judgement and reflect upon it from a universal standpoint, as Kant has suggested two centuries ago.

Yet without the traditional mass media, the public sphere would be lacking of the most effective channel correlating the public(s) with power actors appearing before the public and deriving their legitimacy from it. This (am)bivalent relation between the public and the state mediated through the media is constitutive of publicness. If properly regulated, it is also the precondition necessary for the advancement of the principle of publicity as the supreme ethical and organisational 
principle, superior to property right and freedom of the press that is based on it. Mass media have the central significance in the creation of an institutional (infra)structure enabling the organisation of the general interest both nationally and internationally (globally). The present lack of such an effective communication structure and practical impediments to its creation should become the central issue in the ongoing discussions on media democratisation.

\section{Conclusion}

Historical changes that I have delineated show that freedom of the press "profaned" the principle of publicity. While the principle of publicity denotes a universal belief in freedom and autonomy of human nature and reason, the concept of freedom of the press exemplifies primarily support for the independence and freedom of a privileged social "estate," both in the sense of Marx's "urban estate" (i.e., the new bourgeois class) and in the sense of the press as the fourth estate. The struggle for freedom of thought, freedom of the press, and other civic rights and liberties was essentially an expression of the rise of the new, national bourgeois class - having identified itself with "the society," "the people," or "the nation" and its struggle for power. The idea of the fourth estate accurately pointed to the fact that newspapers emanated from a new, predominantly bourgeois class (estate) and thus had a different source of legitimacy, so that it actually could have represented an important form of control over the traditional branches of state power, but only as long as the press developed as a critical pressure against the old ruling estates of feudal Europe. The bourgeois democratic revolutions suppressed the differentiation in sources of political and social legitimacy, since the same source - the people - legitimised all state powers. In such a situation the press preserved different sources of legitimacy - as an organ of the public and a capitalist non-state enterprise, but the further autonomisation of the press into a particular "estate" based on the power of capital effectively alienated freedom of the press from the universal principle of publicity and specifically from personal positive freedom to express and publish opinions.

Despite the pressure of democratic social movements, however, the developments after the constitution of the bourgeois public sphere and democratic state, and particularly the development of modern mass media - reflected in institutionalised forms and pressures to hinder the range and diversity of opinions in circulation or privileged dissemination of preferred opinions - do not "give rise to healthy institutional structures for the public sphere" (Dahlgren 1995, 12). The principle of publicity was originally conceived as a critical impulse against injustice based on secrecy of state actions and as an enlightening momentum substantiating the region of human liberty and making private citizens equal in the public use of reason. The idea of freedom of the press as the "fourth estate" only sustained the surveillance dimension of the universal principle of publicity. However, the fourth estate model of publicity fails to materialise both key dimensions of the Kantian principle of publicity — it neither guarantees the rightfulness of political decisions nor stimulates the public use of reason. In fact, it can not guarantee the rightfulness of public enactments because it does not stimulate the public use of reason, since only a public capable of reflexive, critical reasoning acquired in public discourse can make reliable judgements. The fourth estate reasoning is based on Tocqueville's partial argument that the sovereignty of the people and the lib- 
erty of the press are correlative: if citizens have the right to participate in the government of society, "everyone must be presumed to be able to choose between the various opinions of his contemporaries and to appreciate the different facts from which inferences may be drawn" (1835, Ch. 11). Tocqueville missed to realise, however, that correlatively to the "sharing in the government" (which not only includes citizen active right to cast a vote but also the passive right to be elected), freedom of publication should include not only the passive right to receive, but also the active right to express opinions.

The concepts of public service media and, to a lesser extent, the model of social responsibility of the press attempted at recuperating the dimension of reflexive reasoning in publicity, but with very limited success. Social changes emanating from convergence of information and communication technologies, and economic, political and cultural globalisation, call for new forms of social-cultural regulation that would fully recognise the universal principle of publicity. Forms of regulation aimed at capacitating the media — as members of the Benthamian "Public Opinion Tribunal" - to control all political (trans)actions are important, but they cannot ensure citizens of participation in deliberative processes. The necessary (though not yet sufficient) conditions of public deliberation are personal involvement and reflective distance: the two components of the process are mutually conditioned and restrained. It is not a disinterested individual who would claim the right of expressing opinions, but rather a citizen conscious of long-term consequences of transactions that are under discussion, who is able to rationalise his or her own involvement, consider arguments of others, and emancipate from prejudices. Personal right to express opinion in public is substantiated by personal involvement. Rational discussion without personal involvement may even degenerate into an "enlightened" absolutism - a position easily adopted by "neutral," "objective," and "disinterested" media of the fourth estate class. In fact, media are never merely means of transmission or "intermediaries" between two parties (e.g., authorities and audiences); they are always the constituting part of the "mediation" (deliberation) process. Bentham was right when he regarded them as "members" of the public opinion tribunal rather than its means.

Reforms of political, economic, and social regulatory practices are needed to open citizens' access to the public sphere and mass media, which can only be based on the legal recognition of the generic human right to communicate, division of labour, and the principle of co-operation - in contrast to the market-driven principles of economic and political competition, separation of powers, and freedom of the press as a separate ("fourth") power. The "right to communicate" and the "fourth

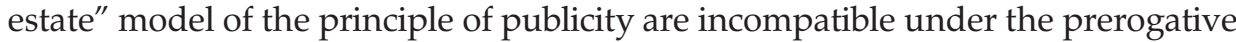
of the right to property. However, under the prerogative of the right to communicate - which does not exclude the property right, but regulates it - the surveillance concept of publicity becomes equivalent to the dimension of "the principle of the legal order" in Kant's principle of publicity, with the only difference being that Bentham's supreme principle of the maximisation of the people's happiness is "replaced" with Kant's principle of rightfulness. Without such a broadening of the deliberative space for the exercise of citizenship bestowed by the right to communicate, in-situ citizens will remain mere consumers of the modern media with an occasional experience, perhaps, of participating in "the public of the letters to the editor." 


\section{Notes:}

1. This article is adapted for Javnost-The Public from my forthcoming book, Principles of Publicity and Press Freedom (Rowman and Littlefield 2002).

2. "Die Freiheit der Feder" (freedom of pen) is in bold types in the German original (Kant 1793, 265).

3. Tönnies argued for the separation of the press from political parties and advertising agencies, because the development of the press as a moral and cultural power presupposed its autonomy from political actions of the state and economic actions of society in the first place. According to Tönnies, the reform should enact ideas and suggestions proposed by a German American, Ferdinand Hansen: (1) in every city the best instructed and educated men should found a completely independent newspaper; (2) all recognized political parties would retain space to introduce and explain events; (3) the newspaper should be independent of advertisers; this would be secured by large circulation, since there would be no need for a party press; (4) only trustworthy firms would receive space for advertising; (5) voices of people would find their direct expression in the newspaper; (6) sensationalism would be excluded; (7) the major articles would be so unbiased, without passion, and objective so that introduced opinions would be accepted with attention and trust; (8) the newspaper should have its own network of correspondents (Tönnies 1922, 575).

\section{References:}

Blumler, Jay G. 1991. Broadcasting Policy in a Changing Information Environment. The Bulletin of Institute of Journalism and Communication Studies (The University of Tokyo) 43, 1-13.

Bentham, Jeremy. 1791/1994. Of Publicity. Public Culture 6, 3, 581-595.

Bohman, James. 1996. Die Öffentlichkeit des Weltbürgers: Über Kants "negatives Surrogat." In M. Lutz-Bachmann and J. Bohman (eds.), Frieden durch Recht: Kants Friedensidee und das Problem einer neuen Weltordnung, 87-113. Frankfurt: Suhrkamp.

Bohman, James. 1999. Citizenship and Norms of Publicity. Wide Public Reason in Cosmopolitan Societies. Political Theory 27, 2, 176-202.

Brighouse, Harry. 1995. Political Equality and the Funding of Political Speech. Social Theory and Practice 21, 3, 473-500.

Cooley, Charles Horton. 1909/1983. Social Organization. A Study of the Larger Mind. New Brunswick: Transaction Publishers.

Dahlgren, Peter. 1995. Television and the Public Sphere. Citizenship, Democracy and the Media. London: Sage.

Dewey, John. 1927/1991. The Public and Its Problems. Athens: Swallow.

Garnham, Nicholas. 1992. The Media and the Public Sphere. In C. Calhoun (ed.), Habermas and the Public Sphere, 359-376. Cambridge, MA: MIT Press.

Guyer, Paul. 2000. Kant on Freedom, Law, and Happiness. Cambridge, UK: Cambridge University Press.

Habermas, Jürgen. 1992. Faktizität und Geltung. Beiträge zur Diskurstheorie des Rechts und des demokratischen Rechtsstaats. Frankfurt: Suhrkamp (Between Facts and Norms. Contributions to a Discourse Theory of Law and Democracy. W. Rehg transl. Cambridge: Polity Press, 1997).

Habermas, Jürgen. 1992a. Further Reflections on the Public Sphere. In C. Calhoun (ed.), Habermas and the Public Sphere, 421-461. Cambridge, MA: MIT Press.

Hoffmann-Riem, Wolfgang. 1986. Law, Politics and the New Media: Trends in Broadcasting Regulation. West European Politics 9, 4, 125-146.

Kant, Immanuel. 1781/1952. The Critique of Pure Reason. Transl. J.M.D. Meiklejohn. (: Great Books of the Western World 42). Chicago: Encyclopaedia Britannica.

Kant, Immanuel. 1785/1952. General Introduction to the Metaphysic of Morals. Translated by W. Hastie. (: Great Books of the Western World 42). Chicago: Encyclopaedia Britannica.

Kant, Immanuel. 1790/1952. The Critique of Judgment. Transl. J. C. Meredith. (: Great Books of the Western World 42.) Chicago: Encyclopaedia Britannica. 
Kant, Immanuel. 1793/1914. The Principles of Political Right. In Immanuel Kant, Eternal Peace and other International Essays, 27-54. Boston: The World Peace Foundation (an abridged translation of the article "Ueber den Gemeinspruch: Das mag in der Theorie richtig sein, taugt aber nicht für die Praxis," Berlinische Monatsschrift, 1793, 2, 201-284. Available at: http://www.ub.uni-bielefeld.de/diglib/Berlinische_Monatsschrift/index-e.htm.)

Kant, Immanuel. 1797/1952. The Science of Right. (The Metaphysics of Morals, Part One). Transl. W. Hastie. (: Great Books of the Western World 42). Chicago: Encyclopaedia Britannica.

MacBride Report. 1980/1984. Many Voices, One World. Communication and Society Today and Tomorrow. Abridged edition. Paris: Unesco.

Marx, Karl. 1844/1974. Zur Judenfrage. In Marx-Engels Werke, 1, 347-377. Berlin: Dietz Verlag.

Mill, John Stuart. 1859/2001. On Liberty. Kitchener: Batoche Books.

Mills, C. Wright. 1956/2000. The Power Elite. Oxford: Oxford University Press.

Milton, John. 1644/1999. Areopagitica. In Areopagitica and other Political Writings, 1-51. Indianapolis: Liberty Fund.

Schudson, Michael. 1997. Why Conversation Is Not the Soul of Democracy. Critical Studies in Mass Communication 14, 4, 297-309.

Slevin, James. 2000. The Internet and Society. Cambridge: Polity Press.

Spinoza, Benedict de. 1670/1883. Theologico-Political Treatise. Transl. by R.H.M. Elwes. Dover Publications. Available at: http://www.spinoza.net/Theworks/index.html.

Spinoza, Benedict de. 1677/1883. A Political Treatise. Transl. by A. H. Gosset. London: G. Bell \& Son. Available at: http://www.constitution.org/bs/poltr-00.htm.

Splichal, Slavko. 1999. Public Opinion. Developments and Controversies in the 20th Century. Lanham: Rowman and Littlefield.

Splichal, Slavko. 2002. Principles of Publicity and Press Freedom. Lanham: Rowman and Littlefield.

Tocqueville, Alexis de. 1835. Democracy in America, Vol. 1. Available at: http:// xroads.virginia.edu/ HYPER/DETOC/toc_indx.html.

Tönnies, Ferdinand. 1922. Kritik der öffentlichen Meinung. Berlin: Julius Springer.

Wilson, Francis Graham. 1962. A Theory of Public Opinion. Chicago: Regnery. 